\title{
THE NARRATIVE ASSAULT ON ISLAM
}

\section{Mustafa Ghani}

Peter the Venerable (d. 1156) is often acclaimed as an early proponent of interfaith understanding for his having commissioned detailed studies of the scriptures of other faiths. This paper considers whether or not such praise is justified by examining Peter the Venerable's representations of Islam's primary sources.

\section{Introduction}

"Even the most persuasive representations — visual or textual—can only be understood fully when observed embedded within the contexts that accredited them and gave them meaning."1

Thus Miri Rubin prefaces her analysis of the relationship between narratives of Jewish host desecration and Christian anti-Semitic persecution. She does not, however, limit the utility of the sort of narrative analysis she advocates to the particular context with which she is working; it is applicable wherever a narrative is invested with meaning by the society that produces it. We might, then, justifiably extrapolate her observation from her specific concerns to consider questions drawn from a very different context: the Cluniac abbot Peter the Venerable's (d. 1156) constructions of Islam. Peter has often been lauded for what some historians have understood as a commitment to interfaith dialogue. In contrast to most early Christian polemicists, who were not especially concerned with accuracy in their depictions of the other, Peter strived to understand other traditions on their own terms. For instance, he commissioned the first entire translation of the Qur'ān and studied passages of the Talmud. Some more recent scholars, including Dominique Iogna-Prat, have cast doubts on his allegedly moderate stance. While Peter did indeed peruse the primary sources of Islam to glean an emic perspective of the faith, this effort only enabled him to launch a more sophisticated critique of Islam. ${ }^{2}$ To assess the value of the Cluniac abbot's contribution, the following questions are worth consideration: Did Peter the Venerable's access to more accurate information about Islam lead him to conceive of the faith fundamentally differently than had earlier Christian authors? What societal functions did Peter the Venerable's depictions of Islam serve? Tentative answers to these questions may emerge if we consider previous representations alongside Peter the Venerable's sources and conclusions on Islam.

\section{Other Depictions of Islam}

Before considering the extent of Peter the Venerable's engagement with Islamic doctrine and practice, it may be valuable to consider earlier and contemporary European depictions of Islam, which constituted the background of Peter's intervention. The rapid spread of Islam, beginning with the reign of the Prophet Muhammad in the seventh century and continuing long afterward, posed difficult problems for Christians in Europe, particularly concerning how to position Islam in a

\footnotetext{
${ }^{1}$ Miri Rubin, Gentile Tales: The Narrative Assault on Late Medieval Jews (Philadelphia: University of Pennsylvania Press, 2004), 2.

${ }^{2}$ Dominique Iogna-Prat, Order and Exclusion: Cluny and Christendom Face Heresy, Judaism, and Islam (1000-1150), trans. Graham R Edwards (Ithaca: Cornell University Press, 2002), 3-4.
} 
Christian economy of history. "Was Islam a heresy, a schism? Was it a parody of Christianity or a new religion, a separate school of thought which deserved respect and recognition? Or was it a joint work of Man and Devil? [...] Why were Muslims so impervious to the appeal of Christianity, when their Qur'an recognized Jesus as Messiah?"4 John Tolan argues that, rather than creating a new category of error to represent the idiosyncratic problems posed by the advent of Islam, "medieval writers would stretch their old language to accommodate Islam, to squeeze it into pre-existing categories rather than rethinking those categories." In general, then, Christian polemicists portrayed Muslims either as a pagan cult or a heretical offshoot of Christianity. While some authors as influential as Norman Daniel have suggested that the former is a more 'popular' image of Islam and the latter is more 'learned,' Tolan disputes this claim, noting that careful examination of primary documents throughout the Middle Ages renders this characterization at best problematic. ${ }^{6}$

\section{Islam as Paganism}

Amongst the earliest and most influential portrayal of Muslims as idolatrous comes from Bede (d. ca. 735), a monk who had virtually no contact with the 'Saracens." In his commentary on Acts 7:43, Bede notes that "the race of the Saracens is enslaved" to a cult "in honor of Venus." "Using the Bible as his guide, Bede apparently had not realized that the cult of Remphan no longer enjoyed currency amongst the Saracens, and that a radically different religion had taken root amongst them. Nonetheless, subsequent European depictions of Islam, at least in part inspired by Bede, tended to cast Muslims as idolatrous - an association that became so entrenched that 'Saracen' almost came to be synonymous with 'pagan,' and was even sometimes used to describe pagans in antiquity. ${ }^{9}$

Norman Daniel has argued that the imputation of idolatry to Islam was not necessarily a consequence of ignorance, but often simply a literary convention. He notes that much poetry made reference to "the Saracens' worship of idols, Mahomet, Tervagan, Apolin and Jupiter." 10 Such depictions often took political significance, as when the Muslims were portrayed, in anticipation of the First Crusade, as worshipping idols of the Prophet Muhammad, particularly in the Dome of the Rock in Jerusalem. According to Daniel, these references were often entirely (and, apparently, selfconsciously) fantastical. For instance, some chansons de geste, especially those set in Carolingian contexts, describe the Arab invasions in much the same terms as they describe pagan invasions; it follows, then, that their religious identities would be analogous. Noting that, in poetry, Saracen

\footnotetext{
${ }^{3}$ A Christian economy of history, as described by FP Pickering, "operates with two truths — that of 'real history'... and the revealed truth of the scriptures of the Christian faith. [...] An official economy of history need not, of course, be Christian, but it must draw its authority (or some of it) from scripture of some kind-Marxist-Leninist, for instance" (165). See Frederick P Pickering, "Economies of History. What is Fiction?" in Essays on Medieval German Literature and Iconography (Cambridge: Cambridge University Press, 1980), 164-174.

${ }^{4}$ Minou Reeves, Muhammad in Europe (New York: New York University Press, 2000), 2.

${ }_{6}^{5}$ John V Tolan, Saracens: Islam in the Medieval European Imagination (New York: Columbia University Press, 2002$), 19$.

${ }^{6}$ Tolan, Saracens, 136.

7 'Saracen' is the term by which medieval Christians knew Muslims. Its etymology is uncertain. John Tolan lists several possibilities, including their alleged descent from Sarah, the wife of Abraham (a curious claim, given that the Arabs claim descent from Hagar); their alleged Syrian descent; or their alleged origin in the apparently fictional town of Sarras. See Tolan, Saracens, 127-28, 287n25. The Online Etymology Dictionary reports speculation that the term originates with the Arabic sharqyizin, or Easterners. In its original sense, the word was used by Greeks and Romans to designate nomads of the deserts of Syria and Arabia. See "Saracen," Online Etymology Dictionary, accessed December 28, 2011, http://www.etymonline.com/index.php?term=Saracen.

${ }^{8}$ Qtd. in Tolan, Saracens, 73.

${ }^{9}$ Tolan, Saracens, 73-74, 126-27.

${ }^{10}$ Norman Daniel, Islam and the West: The Making of an Image (Oxford: Oneworld Publications, 2000), 338.
} 
heroes tend to be portrayed much more sympathetically than in polemical works, Daniel adds, "It is hard to see that these are intended as other than fun."11

While Daniel's argument may be valid, it perhaps too quickly glosses over the function such depictions may have served within their societal contexts. If the pagan tradition to which they belonged were not the litholatry of their ancestors, Muslims were often portrayed as adherents of a cult that bore great similarity to pre-Christian Roman paganism. ${ }^{12}$ Challenging Daniel's argument, Tolan emphasizes that these depictions fueled the jingoistic propaganda that propelled the first and second Crusades. If Islam were merely a continuation of Roman paganism, then Christians combating the Saracen lords of Jerusalem were continuing the work of the apostles. ${ }^{13}$ Abetting the liberation efforts was thus "part of the age-old struggle with paganism" and would culminate in the eradication of idolatry and Christ's second coming. ${ }^{14}$

Given that the Roman authorities shared blame with the Jews for having crucified Christ, Tolan makes the important point that Saracens were thus indirectly implicated in accusations of deicide, providing further justification for the Crusade. ${ }^{15}$ Indeed, opposing the Saracens in Jerusalem may have assumed a similar signification to persecuting the Jews in the diaspora: "Present violences resonated with violences past and eternal, and a local topography transmuted into a sacred landscape." ${ }^{\prime 16}$ Artistic constructions of the role of Saracens in Christian sacred history consequently provided Christian readers with insight into "the sacrificial act from which their history originated" and proposed the Saracen's "function in Christian genealogy and society," providing for an "integrative" conception of history. ${ }^{17}$ This conception allowed the Christian soldier to "make sense of the struggles [he] faced, the risks [he] ran, the death [he] or [his] comrades faced."18

\section{Islam as a Christian Heresy}

For many authors, the Saracens were clearly not idolaters, but were heretics of some sort. Some, for example, conflated the Prophet Muhammad with a heresiarch mentioned in the New Testament, Nicholas, - a notion that Peter the Venerable later sought to correct-while others believed the Prophet to have been either a Roman cardinal frustrated in his bid for the papacy or influenced by one. ${ }^{19}$ Given that Peter the Venerable received his information about Islam from Toledo, however, I will, for the purpose of this paper, focus on Spanish constructions of Islam as a heresy.

Contrary to most European depictions of Islam, Mozarabic (from the Arabic musta'rib, or 'Arabized') Christian discourse tended to be somewhat sophisticated. Developed largely in the Iberian Peninsula, Mozarabic critiques of Islam derived from three sources: "Muslim holy writings (in

11 Ibid.

12 Tolan, Saracens, 106.

13 Tolan, Saracens, 111-12.

14 Tolan, Saracens, 109, 126.

15 Tolan, Saracens, 121.

${ }^{16}$ I Clendinnen qtd. in David Nirenberg, Communities of Violence: Persecution of Minorities in the Middle Ages (Princeton: Princeton University Press, 1998), 217.

${ }^{17}$ Nirenberg, Communities of Violence, 215.

18 Tolan, Saracens, 121. Tomaz Mastnak describes how, from the seventh century until the Crusades, Christian views of Muslims became increasingly hostile, until Muslims were eventually identified as the enemy of Christendom. See Tomaž Mastnak, Crusading Peace: Christendom, the Muslim World, and Western Political Order (Berkeley: University of California Press, 2002), 105-12.

${ }^{19}$ Daniel, Islam and the West, 104. 
particular Qur'ân and Hadith), Eastern anti-Muslim polemic, and Latin theology." 20 For example, such writers in the ninth-century as Paul Alvarus and Eulogius labelled the Prophet Muhammad a heresiarch and an Antichrist (or precursor to the Antichrist) because of his rejection of Jesus' divinity. ${ }^{21}$ What motivated the vitriol characteristic of many Mozarabic polemics was the growing crisis beginning in the eighth century and extending into the thirteenth whereby the Muslims gained not only military ascendency over the Christians, but also cultural and intellectual ascendency, such that many Christians had abandoned the study of Latin in favour of Arabic and often felt intellectually drawn to Islam. ${ }^{22}$ Drawing from Edward Said, Tolan argues that Mozarabic apologies for Christianity were a historiographical expression of 'resistance culture,' which "reshape[s] history, creating a historiography of resistance to oppose the triumphalist historiography of the dominant regime. [...Mozarabic polemicists] oppose the Muslim triumphalist view of history with an apocalyptic vision promising Christian vengeance." 23 Apparently, these narratives functioned not only to locate Muslims within a Christian worldview, but also to enforce a communal sense of identity.

\section{Background to Peter the Venerable's Study of Islam}

In 1142, Peter the Venerable travelled to Spain, throughout which he spent several months touring, on the invitation of Emperor Alfonso VII. The invitation was probably provoked by the Emperor's promise to donate a large sum to Cluny, as well as to ensure Peter the Venerable's support of the Emperor's candidate for the archbishopric of Santiago. ${ }^{24}$ What emerged from this trip would have much wider ramifications for European intellectual history; in the course of his travels through Spain, Peter conceived and planned the undertaking of a scholarly investigation into the primary sources of Islam that would eventually provide the foundation for a sustained attack on the alien faith. $^{25}$ The possibility of this venture probably occurred to Peter during his visit to Toledo, which, by the twelfth century, was undergoing a sort of "renaissance" in terms of translation and dissemination of key Arabic treatises in mathematics and the physical sciences. There, Peter assembled a team of translators to translate into Latin certain texts-what came to be called the Collectio toletana, or the Toledan Collection - that would prove indispensible for a more sophisticated Christian polemic against Islam. ${ }^{26}$

\section{The Toledan Collection - Texts and Translators}

The Collection consisted of five texts. The source of the first, the Fabulae Saracenorum, is difficult to identify, because the translator omitted the chains of narration for their being meaningless to the average Latin reader. It consists of accounts of the creation of the World and biographies of early prophets and sages, the Prophet Muhammad, and the first caliphs. Another text in the Collection, the Liber generationis Mabumeth, was a translation of Kitäb Nasab Rasul-Alläh, which recounts the story of a light (nür Muhammadi) being passed between generations of ancestors until its corporeal realization in the person of the Prophet Muhammad. Also commissioned was the Doctrina

\footnotetext{
${ }^{20}$ John V Tolan, "Introduction," in Medieval Christian Perceptions of Islam: A Book of Essays, ed. John V Tolan (New York: Garland Publishing, 1996), xv. Tolan, Saracens, 83-84.

${ }^{21}$ Tolan, Saracens, 78, 90-93, 103.

22 Tolan, Saracens, 86.

23 Tolan, Saracens, 91. For more on 'resistance culture,' see Edward Said, Culture and Imperialism (New York: Random House, Inc., 1994), 209-20.

${ }^{24}$ James Kritzeck, Peter the Venerable and Islam (Princeton: Princeton University Press, 1964), 10-12.

${ }^{25}$ Kritzeck, Peter the Venerable and Islam, 14.

${ }^{26}$ Kritzeck, Peter the Venerable and Islam, 51-53.
} 
Muhammad, a translation of Masä'il 'Abd-Allah b. Saläm, which recounts an apocryphal tale of four Jews posing questions to the Prophet and the latter's alleged responses - many of which are, at best, problematic theologically. The last two texts, which will be examined in some detail for their utility to Peter the Venerable, were the Latin translations of the Qur'ān and Risälat al-Kindī, an early Christian polemic against Islam. ${ }^{27}$

For the accomplishment of this project, Peter the Venerable enlisted the aid of a team of five translators. Little is known about the first, Peter of Toledo. He probably coordinated the group and provided annotations to the translations. The translation of Risalat al-Kindi is attributed to Peter of Toledo. Owing to Peter of Toledo's deficiencies in Latin, the work had to be edited by Peter of Poitiers, another member of the team. Peter of Poiters was the secretary of Peter the Venerable, and may have been responsible, along with Peter of Toledo, for revising and organizing the Toledan Collection. He may also have played a significant role in the composition of Peter the Venerable's assessment of Islamic doctrine, the Summa totius haeresis Saracenorum. Also in the group were Robert of Ketton, about whom more will be mentioned presently, and Herman of Dalmatia, whom Peter the Venerable acclaimed as a brilliant scholar. Intimate companions, Robert and Herman had been collaborating for years on translations of seminal texts of mathematics and astronomy before responding to Peter the Venerable's call. Robert translated the Qur'ān and the Fabulae Saracenorum, while Herman translated the Liber generationis Mabumeth and the Doctrina Mubammad. Least of all is known about the final member of the team, an Arab named Muhammad, who, for lack of any more information, is impossible to identify. Nonetheless, his presence in the team was significant in that, for Peter the Venerable, it provided a greater warrant of authenticity. ${ }^{28}$

\section{Robert of Ketton and the Translation of the Qur'ān}

Perhaps the most important and memorable member of Peter the Venerable's team of translators was Robert of Ketton (d. ca. 1160), widely credited with completing the first translation of the entire Qur'ān, which he titled provocatively, Lex Mahumet pseudoprophete (The Law of the Pseudo-Prophet Muhammad). His principal interest, however, was the "study of astronomy and geometry," having been distinguished in his earlier career principally for his translation of al-Khwarazmì's Al-Kitäb alMukbtașar fi Hisāb al-Jabr wa al-Muqäbalah, rendered in Latin as Liber algebrae et Almucabola. All his previous distinctions, however, were far overshadowed by his translation of the Qur'ān, which, according to Norman Daniel, achieved wide dissemination and became the standard translation of the Qur'ān in Europe for centuries afterward. ${ }^{29}$

Despite such widespread success, Robert's translation has been heavily criticized for taking excessive liberties with the text. For example, Juan de Segovia (d. ca. 1458), the earliest known critic of Robert's translation, objected to Robert's rearrangement of the text and his frequent interpolations and deletions. ${ }^{30}$ Criticisms in a similar vein were reproduced in several subsequent assessments of the value of the Lex Mabumet. Dismissals of the translation as unfaithful to the original text have persisted into the present. Given that this translation was a major source upon which Peter the

\footnotetext{
${ }^{27}$ The information about the translations is summarized from Kritzeck, Peter the Venerable and Islam, 75-107.

${ }^{28}$ The information about the translators is summarized from Kritzeck, Peter the Venerable and Islam, 56-69.

${ }^{29}$ Daniel, Islam and the West, 279. Muzaffar Iqbal, “The Qur'ān and its Disbelievers,” Islam \& Science 7.2 (2009): 92.

30 Thomas E Burman, "Tafsìr and Translation: Traditional Arabic Qur'ān Exegesis and the Latin Qur'āns of Robert of Ketton and Mark of Toledo," Speculum 73.3 (1998): 705. In Burman's opinion, de Segovia offers the "fairest critique of the Lex Mabumet," and thus it is cited here as a representative example of the sort of criticisms that have since emerged. Burman discusses these criticisms at greater length in "Tafsir and Translation," 705-07.
} 
Venerable based his anti-Muslim polemics such criticism could, of course, have massive ramifications for the accuracy of Peter's construction of the Saracen.

Distinguishing himself from what approaches "scholarly consensus," Thomas Burman intervenes to suggest that, while the Lex Mabumet does frequently depart from the literal signification of the text, it does not necessarily misrepresent "what Muslims themselves thought to be the meaning of the Qur'ān." 31 In part, Burman takes his cue from Rita Copeland, who, commenting on the medieval commentary tradition, notes that in many cases, "Latin commentary is largely constituted by textual paraphrase, which takes over and surrounds the text." 32 She argues that "at all levels vernacular translation defines itself through the established structures of hermeneutic activity," suggesting that the distinctions between "rhetoric, hermeneutics, and translation" are, at best, tenuous. ${ }^{33}$ To establish his premise, Burman locates the origin of many of the idiosyncrasies of the translation within the Muslim exegetical tradition itself_-and thus, his text, if not as mimetic of the original as Mark of Toledo's attempt nearly a century later, nonetheless is often more representative of "the received, Muslim understanding of that sacred book.",34

As a representative example, Burman cites Robert of Ketton's translation of the twenty-eighth verse of the second chapter of the Qur'ān. In his interpretation of the text, Robert renders the Arabic "wakuntum amwätan fa-ahyäkum" - what literally reads, "and you were dead, then He gave you life" —as "he, drawing you out of non-being into life...". This figurative interpretation, if even it seems appropriate to the context, looks suspect-until, of course, we consider how Muslim commentators understood the verse. Burman invokes interpretations reported by al-Tabarī (d. 923), al-Zamakhsharī (d. 1144), and ibn Kathīr (d. 1373), all of which suggest that, indeed, "death" in this context is a metaphor for the non-being that precedes existence. ${ }^{35}$ Throughout the rest of his paper, Burman continues in similar fashion: he identifies certain problematic passages, selected apparently at random from the beginning, middle, and end of the Qur'ān, examines Robert's translations, and compares them to the sayings of the exegetes.

Though Burman puts forth a compelling argument, it is not unproblematic. While many of the examples he poses of Robert of Ketton's interpretations of problematic Qur'ānic passages strongly suggest that Robert regularly consulted exegetical literature, a dearth of historical sources prevents us from determining exactly what he was reading. Robert himself does not identify any commentaries that he consulted. In the absence of such evidence, and in lieu of grappling with the entirety of the unfathomably large exegetical corpus, Burman relies heavily on a few authoritative commentaries to prove his point. Certainly these contributions represent standard references today, but did they enjoy the same currency amongst Muslims in twelfth-century Toledo? For instance, could the Persian alZamakhsharî's commentary have achieved such wide dissemination as to have reached the Muslims in Spain within a little more than a decade of its completion? ${ }^{36}$ It may be possible, but Burman does not take up the question.

\footnotetext{
31 Burman, "Tafsir and Translation," 707.

32 Rita Copeland, Rhetoric, Hermeneutics, and Translation in the Middle Ages: Academic Traditions and Vernacular Texts (Cambridge: Cambridge University Press, 2003), 92.

${ }^{33}$ Ibid.

${ }^{34}$ Burman, "Tafsir and Translation," 708. The comparison should not suggest, however, that Mark of Toledo did not consult exegetical literature. It would seem that he did, albeit much more sparingly than did Robert of Ketton.

35 Burman, "Tafsir and Translation," 709-11.

${ }^{36}$ A brief, useful history of the exegetical tradition is given in Muhammad al-Fāḍil b. 'Āshūr, Al-Tafsìr wa-Rijäluhū (Cairo: Al-Azhar, 1970).
} 
In some sense, though, whether or not Robert was reading the specific commentaries upon which Burman relies is irrelevant. After all, most commentaries "reiterate[ much of what earlier commentators had said" 37 - this is the basis, for instance, on which Burman justifies his appeal to ibn Kathīr, who lived and wrote long after the death of Robert of Ketton. While that premise is true, it nonetheless elides the vast differences within the Islamic exegetical tradition. Many of these variant opinions arise from divergent interpretive principles, codified in the discipline of ușül al-tafsìr or exegetical hermeneutics, or are a consequence of the vastly different cultural contexts-spanning centuries of development and a geographical region extending over lands as far separated as West Africa and the Nusantara-in which the commentators resided. Even a single tafsir, such as alTabarî's, as Burman notes, might bring together several opinions about a single verse. ${ }^{38}$ On what basis, then, did Robert make his choices? And even if the choices he made were consonant with the choices of particular exegetes, what guarantees that these same opinions were current amongst Muslim scholars in Toledo, such that Robert's translation would resonate with (an apparently monolithic) "received, Muslim understanding of that sacred book?",39

Naturally, Robert's translation is not an innocent text, nor is it a disinterested scholarly endeavour. Invoking Michel Foucault, Edward Said cautions that we ought not to divorce a text from the context of its production: "its affiliation with institutions, offices, agencies, classes, academies, corporations, groups, guilds, ideologically defined parties and professions." 40 Indeed, the very circumstance that occasioned Robert's translation-not to mention the general character of the intellectual and religious culture in which it was produced-rendered a disinterested study of Islam's primary source impossible. ${ }^{41}$ To his credit, Burman is careful to emphasize this point, providing that caveat that to assume Robert's Christian biases would never surface in his opus would be foolish, even if actively polemical distortions, as he consistently argues, were rare, and the translator's choices frequently found precedents in the classical commentaries. ${ }^{42}$ On the other hand, Norman Daniel identifies in Robert a persistent liability "to heighten or exaggerate a harmless text in order to give it a nasty or licentious ring, or to prefer an improbable but unpleasant interpretation of the meaning to a likely but normal one." 43 While Burman does suggest why Robert may have made some of his interpretive choices, much more can be done to propose how particular choices may have served Peter the Venerable's polemical project. The upshot of this discussion is that it may be a valuable scholarly endeavour to undertake a much more extensive study of Robert's text: In what ways does it reflect the polemic impetus for its production? How might it be located within the classical exegetical tradition? Does it accurately represent contemporary Muslim readings of the Qur'ān?

Whether or not Robert of Ketton's translation would have resonated with contemporary Muslims might be partly answered by examining Muslim attitudes towards translating the Qur'ān. In general, the Qur'ān resists translation. Hussein Abdul-Raof notes, "For Muslims, the divine Word assumed a specific, Arabic form, and that form is as essential as the meaning that the words convey. Hence

\footnotetext{
${ }^{37}$ Burman, "Tafsir and Translation," 712.

${ }^{38}$ Ibid.

${ }^{39}$ Burman, "Tafsir and Translation," 708.

${ }^{40}$ Edward Said, “The Problem of Textuality: Two Exemplary Positions," Critical Inquiry 4.4 (1978): 701.

${ }^{41}$ Muzaffar Iqbal, "Reading the Qur'an in Latin Christendom, 1140-1560 (Review)," Islam \& Science 6.1 (2008): 58.

42 Thomas E Burman, Reading the Qur'an in Latin Christendom, 1140-1560 (Philadelphia: University of Pennsylvania Press, 2007), 28.

${ }^{43}$ Daniel, Islam and the West, 165.
} 
only the Arabic Qur'an is the Qur'an, and translations are simply interpretations." ${ }^{\text {,4 Anxiety }}$ surrounding misrepresentation dates back to the time of the Companions of the Prophet; though some did venture to interpret difficult passages, others were more reticent. ${ }^{45}$ Although some modern scholars have argued that, because the Qur'an is inimitable, any attempt at translation is impermissible, early Muslims made notable attempts to translate the Qur'ān. ${ }^{46}$ However, when translation was undertaken in the first few centuries following the advent of Islam, its authors frequently attempted to mimic Arabic diction and syntax as closely as possible-even at the expense of the target language. ${ }^{47}$ Such early Muslim translations, as well as comparable non-Muslim efforts like that of Mark of Toledo, would be classified by Waleed al-Amri as lafži, or literal; whereas a text as liberal as that of Robert of Ketton would, no doubt, qualify as ma'nawi, or figurative. ${ }^{48}$ The distinction is, however, tenuous: in both cases, we ought not to lose sight of the fact that the translator has great agency in how he constructs the text in the destination language, and alleged intertextual allusions suggest that both approaches involved fairly frequent consultation of the exegetical literature. $^{49}$

In sum, though Peter the Venerable had an advantage over other Christian authors covering Islam in that he had access to the Qur'ān through translation, the probity of the translation is, at best, questionable. Nonetheless, he was consequently more well-informed about Islam than most of his contemporaries.

\section{The Translation of Risālat al-Kindī}

Perhaps more valuable to Peter the Venerable than the Qur'ān translation, though, was Risālat alKindī. The text is attributed to 'Abd al-Masịh b. Ishāa al-Kindī, which is probably a pseudonym. Its authorship and dating are unclear, though it must have been composed before the eleventh century. ${ }^{50}$ Translated into Latin as the Epistola Saraceni et Rescriptum Christiani, the text served for many Latin readers as their major reference on Islam, despite its selective inclusion of detail and colouring of historical events with unflattering interpretations-all of which were presumably deemed unproblematic retellings of historical reality. These readers were not necessarily to blame for their ignorance, given that Risalat al-Kindi was the only access a Latin reader of the period would have had to the life of the Prophet. Accurate information about the Prophetic biography was as hard to come by in Europe after Peter the Venerable's intervention as it was before. ${ }^{51}$

\footnotetext{
${ }^{44}$ Hussein Abdul-Raof, Qur'an translation: discourse, texture and exegesis (Richmond: Curzon Press, 2001), 19.

45 Waleed B Al-Amri, “Qur’ān Translation and Commentary: An Uncharted Relationship?,” Islam \& Science 8.2 (2010): 86. The Hanafi jurist, Khalī al-Naḥlāwī, has a useful, if brief, discussion of the conditions pertaining to interpreting the Qur'ān by personal opinion in al-Durar al-Mubaḥah fi al-Haẓr wa al-Ibähah. The relevant section is translated in Ahmad b. Naqīb al-Mișrī, Reliance of the Traveller: A Classical Manual of Islamic Sacred Law, trans. Nuh HM Keller (Amana Publications: Beltsville, 1999), 751-52.

46 Abdul-Raof, Qur'an Translation, 20. Al-Amri has a useful discussion about modern debates concerning the permissibility of translating the Qur'ān. See al-Amri, “Qur'ān Translation and Commentary," 89-92. This tradition runs contrary to James Kitzeck's sweeping claim that "there has been and remains in Islam a strong prohibition against translating the Koran into other languages" (Kritzeck, Peter the Venerable and Islam, 99.).

47 Abdul-Raof, Qur'an Translation, 20.

48 Abdul-Raof uses the terms "semantic" and "communicative" respectively. See Abdul-Raof, Qur'an Translation, 21.

${ }^{49}$ Burman, Reading the Qur'ān, 40.

${ }^{50}$ Daniel, Islam and the West, 22. James Kritzeck notes that al-Bīrūnī (d. 1048) said the work was contemporary to his time and Massignon dates it at the beginning of the tenth century. See Kritzeck, Peter the Venerable and Islam, 102.

${ }^{51}$ Daniel, Islam and the West, 114-15.
} 
For all its problems, however, Risälat al-Kindì may have been the most important contribution to the Toledan Collection-more important, even, than the translation of the Qur'ān. The text was acclaimed not only for the acuity of its argument, but also for the fact that, issuing from a Muslim polity, it emanated an air of authenticity. Indeed, its influence extended even to those who had not seen an actual copy of the text in either Latin or Arabic. ${ }^{52}$ Many of its arguments are echoed in Peter the Venerable's own refutation of Islam, Contra sectam Saracenorum. ${ }^{53}$

The text stages what is probably a fictional correspondence between a Muslim, 'Abd-Allāh b. Ismā'îl al-Hāshimī, and a Christian, the aforementioned al-Kindī. The letters were purportedly read aloud in the court of the ninth-century caliph al-Ma'mūn. Opening the text is Al-Hāshimî̀s purported letter, in which he extends an invitation to al-Kindī to embrace Islam. He describes certain aspects of Islamic practice, including the five pillars of Islam (of which al-Kindī would doubtless have been aware anyway), and then tries to seduce al-Kindī to convert with the promise of sensual delights in Paradise and the opportunity to marry up to four wives. (Accusations of sexual debauchery are a common motif in Christian anti-heretical literature. ${ }^{54}$ The case for Islam is so unconvincing that it seems probable that it was fabricated by a Christian.

In response, al-Kindī issues his friend a detailed, complex refutation of Islam. He begins with a forceful defence of the Trinity, arguing that the Qur'ān misrepresents the concept. He then proceeds to consider the Prophet Muhammad, whom he praises for having sought to reform the religious character of his people, but with whom he nonetheless finds much fault. Of greatest significance is his questioning the validity of the founder of Islam's claim to prophecy and his assertion that the latter did not perform any miracles-both arguments that would later be taken up by Peter the Venerable in his polemic. While al-Kindī does not address the position of Muslims relative to Christianity directly, he is careful to document the Prophet's purported seeking of assistance from Bahịrá, a Nestorian monk; and 'Abd-Allah b. Salām and Ka'b al-Aḥbār, two former rabbis. The portrayal would seem to suggest that al-Kindī considered Islam a sort of heretical offshoot of the Judeo-Christian tradition. That thesis is complicated, however, by his insistence that several Islamic practices, such as the pilgrimage to Mecca and nuptial legislation, are of pagan origin. ${ }^{55}$

In assembling the Toledan Collection, Peter the Venerable's purpose was to provide his coreligionists with accurate information about Islam. He did not initially intend to refute the faith, instead trying to delegate that task to Bernard of Clairvaux, whom he considered more qualified. He thus addressed the latter in 1144, pleading him to compose an apology against Islam, and enclosed a translation of Risälat al-Kindi along with his own epitome of Islamic doctrine, the Summa totius haeresis Saracenorum. There is no evidence that Bernard reciprocated the correspondence, and in any case, Peter the Venerable undertook the task himself.

\section{Peter the Venerable's Depiction of Islam}

Hardly a disinterested document, Peter the Venerable's Summa reveals what he understood to be the role of the Saracens. It begins, of course, with the major point of contention that divides Christians and Muslims: the nature of Christ. Peter writes:

\footnotetext{
${ }^{52}$ Daniel, Islam and the West, $256-57$.

${ }^{53}$ Kritzeck, Peter the Venerable and Islam, 104.

54 Tolan, Saracens, 146.

55 Kritzeck, Peter the Venerable and Islam, 101-05. Of note is that Ka'b al-Ahbār did not actually meet the Prophet Muhammad, but rather entered Medina and embraced Islam during the caliphate of 'Umar. See Muhammad al-Dhahabī, Siyar A'lām al-Nubalā' (Beirut: Mu'assasat al-Risālah, 1981), 5:488.
} 
Furthermore, these blind ones deny that God the creator is Father, for, according to them, no one becomes a father without sexual intercourse. And consequently they do not believe that Christ, though conceived of the Holy Spirit, is the son of God, or God, but [only that he is] a good prophet, most true, free from all falsehood and sin, the son of Mary, born without a father, [and] never having died, because it was not fitting that he should die. On the contrary, [they believe that] when the Jews wanted to kill him, he ascended to the heavens, having escaped out of their hands, and [that] he lives now in the flesh in the presence of the creator until the coming of the Antichrist. ${ }^{56}$

What Peter seemed to have struggled over-understandably, of course-was that, even if the Saracens accepted and revered Jesus Christ, they nonetheless did not recognize his divinity. They even acknowledged his miraculous birth and ascension to heaven-but at the same time denied the incarnation. Did they, then, merely represent a new strain of Christian heresy? But how could they be heretics if the leader of their sect, as Peter would proceed to argue, lived as "an idolater amongst idolaters?"57

Indeed, no clear answer emerges immediately in the Summa. Peter argues that, under the instruction of Bahīrá, the Prophet Muhammad studied the Old and New Testaments and embraced Nestorian Christianity. ${ }^{58}$ On this basis, Peter continues, "[Muhammad] tried to lead [his people] bit by bit from idolatry: not, however, to the true God, but to the error of his own heresy." 59 To make matters worse, the Prophet was abetted in his purpose by the Jews: "And in order that the whole fullness of iniquity should come together in Mohammed, and that nothing should be lacking for his damnation and that of others, Jews were joined to the heretic. [... They] hissed to Mohammed not the truth of the scriptures, but their own fables in which they abound even now." ${ }^{\prime 60}$ In other words, lacking a precise notion of where the Saracens fit within the catalogue of error, Peter decided, perhaps somewhat sloppily, that the Saracens embraced all "the different figures of the Antichrist.",61 Elsewhere in the Summa he is explicit about his uncertainty: "I cannot clearly decide... whether the Mohammedan error must be called a heresy and its followers heretics, or whether they are to be called pagans." ${ }^{, 62}$ It was clear enough to Peter that the Muslims were not idolatrous, but he nonetheless did not discount the 'heathen' label, given Islam's alleged pagan origins and the Muslims' rejection of Christian sacraments. In some sense, then, despite his having more accurate sources on Islam than most European polemicists, ${ }^{63}$ Peter the Venerable did not radically reconfigure previous positionings of Islam relative to Christianity, likely because he read the sources not out of some ecumenical urge to embrace the other but rather with much the same intent as other Christian polemicists: to identify error.

\footnotetext{
${ }^{56}$ Qtd. in Kritzeck, Peter the Venerable and Islam, 119.

${ }^{57}$ Qtd. in Kritzeck, Peter the Venerable and Islam, 127.

${ }^{58}$ Kritzeck, Peter the Venerable and Islam, 129.

${ }^{59}$ Qtd. in Kritzeck, Peter the Venerable and Islam, 127.

${ }^{60}$ Qtd. in Kritzeck, Peter the Venerable and Islam, 131.

${ }^{61}$ Iogna-Prat, Order and Exclusion, 4.

${ }^{62}$ Qtd. in Kritzeck, Peter the Venerable and Islam, 143.

63 The exception, of course, are Christians in the Iberian Peninsula, whose familiarity with Arabic and daily contact with Muslims left them generally more well-informed about Islam than even Peter the Venerable himself.
} 
If for no other reason than convenience, Peter generally dealt with the Saracens as heretics. ${ }^{64}$ In opposing Islam, Peter casts himself as reviving the patristic legacy, which developed as a response to early deviations from what was understood as orthodox Catholic doctrine. ${ }^{65}$ Despite his procurement of the Toledan Collection, Peter was by no means an expert on Islam; though he did attempt, in contrast with many previous Western European polemicists, to engage Islam on its own terms, he felt much more comfortable with the Christian textual tradition in which he was trained. He thus devotes the opening section of his refutation, the Contra sectam Saracenorum, ${ }^{66}$ to proving, using reason, that Saracens must recognize the divine nature of earlier scriptures. The appeal to reason serves a double purpose. First, insofar as all men are "endowed with reason," arguing for Christianity by reason establishes the universal applicability of its truths. ${ }^{67}$ Second, Peter the Venerable's logic enables him to shift the argument to his particular expertise: disputation based on authority. ${ }^{68}$ Such disputation presupposes that those who are addressed (putatively the Muslims, despite the fact that most Muslims ${ }^{69}$ would never have had access to the Latin treatise) will, on some level, recognize those authorities. In other words, the logic of Peter the Venerable's argument implies that he considers the Saracens closer to heretical Christianity than to outright heathenism. ${ }^{70}$

All the same, Islam posed specific problems that pre-empted its identification with any Christian heresy that had preceded it. ${ }^{71}$ On the basis of much reflexion, Peter thus forwards the curious conclusion that the Prophet Muhammad was an intermediary figure between the heresiarch Arius and the Antichrist:

Arius began by denying that Christ was the one true Son of God and calling him a creature, the Antichrist will finally bring to its completion by asserting that he was not only not God or the Son of God, but not even a good man. This most wicked

\footnotetext{
64 Given that the Muslims represented the consummation of all error, it was of little import whether they were predominantly pagans or heretics: "Choose... whichever you prefer," Peter says. (Qtd. in Kritzeck, Peter the Venerable and Islam, 144.)

${ }^{65}$ Kritzeck, Peter the Venerable and Islam, 141. Iogna-Prat, Order and Exclusion, 128. John V Tolan, Sons of Ishmael: Muslims through European Eyes in the Middle Ages (Gainesville: University Press of Florida, 2008), 59.

66 The refutation is considered only in passing because Peter the Venerable largely develops his positioning of Islam relative to Christianity in the Summa, which is addressed to a Christian audience and aims to educate the reader about how to understand the place of Islam. In general, the Contra sectam Saracenorum simply develops certain arguments found in Risälat al-Kindì.

${ }^{67}$ The quotation is from Peter the Venerable as cited in Kritzeck, Peter the Venerable and Islam, 161. The idea of reason serving as a guarantor of universality is developed in Iogna-Prat, Order and Exclusion, 144-46.

${ }^{68}$ Kritzeck, Peter the Venerable and Islam, 183.

${ }^{69}$ (including, regrettably, the author of this paper...)

${ }^{70}$ Interestingly, though Peter the Venerable expects that he will be successful in appealing to reason when disputing with Muslims, he is much more pessimistic concerning the Jews, whom he disparages as beasts deprived of intellect. Tolan writes, "Aware that [the Jews] have withstood centuries of such argumentation, he prefers to impute this to their lack of human reason, to their 'bovine intellect,' than to any lack of rational basis for Christian truth." (Tolan, Sons of Ishmael, 51.). His confidence that the Muslims are more likely to accept his reasoning perhaps hearkens to the common reliance of the Muslim and Christian scholarly traditions upon Aristotelian logic. On the other hand, according to Sergey Dolgopolski, "[T] The Talmudic masters intrinsically turn to both philosophy and sophistry/rhetoric without, however, conflating their position with either of them" (Sergey Dolgopolski, What is Talmud?: The Art of Disagreement (New York: Fordham University Press, 2009), 158.). In other words, the Jews were not 'irrational' as such, but rather approached rationality differently than did the Christians or Muslims.

${ }^{71}$ Daniel, Islam and the West, 209.
} 
Mohammed seems to have been appropriately provided and prepared by the Devil as the mean between these two. ${ }^{72}$

What is remarkable about this conception is that Peter the Venerable draws a teleological progression to incorporate a history of errors. By projecting Biblical truth into a forward trajectory, the logic of the teleology serves to explain why Islam is not explicitly accounted for in the Bible. The narrative operates in much the same sense that Hayden White predicates of Organicist conceptions of history:

Organicist world hypotheses and their corresponding theories of truth and argument are relatively more 'integrative' and hence more reductive in their operations. The Organicist attempts to depict the particulars discerned in the historical field as components of synthetic processes. At the heart of the Organicist strategy is a metaphysical commitment to the paradigm of the microcosmic-macrocosmic relationship; and the Organicist historian will tend to be governed by the desire to see individual entities as components of processes which aggregate into wholes that are greater than, or qualitatively different from, the sum of their parts. Historians who work within this strategy of explanation... tend to structure their narratives in such a way as to depict the consolidation or crystallization, out of a set of apparently dispersed events, of some integrated entity whose importance is greater than that of any of the individual entities analyzed or described in the course of the narrative. [...] $[\mathrm{H}]$ istory written in this mode tends to be oriented toward the determination of the end or goal toward which all the processes found in the historical field are presumed to be tending. ${ }^{73}$

In like fashion, Peter the Venerable positions Islam within a pre-existing eschatological narrative. Islam becomes a microcosm or synecdoche of the larger narrative of the end of times and the coming of the Antichrist. As an individual event in the development of that trajectory, Islam does not have any intrinsic significance, but rather is important in that it presages the end. Thus, its not being presaged in the Bible is justified.

Perhaps more importantly, the narrative allows Christians to make sense of their own history, and their own sense of identity. The advent of Islam, according to this conception, bears witness to the impending coming of the Antichrist. In this sense, it confirms Said's argument: "in the work of Peter the Venerable and other Cluniac Orientalists... the Orient and Islam are always represented as outsiders having a special role to play inside Europe."74 Peter "found a place for Islam... in a familiar and identifiable relation to the whole truth that the Church represents." 75 Islam was not simply an other that had to be confronted; rather, that confrontation had profound ramifications for the Christian idea of self. Perhaps for this reason Peter the Venerable felt drawn to an Organicist narrative mode; after all, one of the major problems with which he dealt and one of his explicit motivations was to explain the ascendancy of Islam and the consequent swell in apostasy from

\footnotetext{
72 Qtd. in Kritzeck, Peter the Venerable and Islam, 145.

73 Hayden White, Metahistory: The Historical Imagination in Nineteenth-Century Europe (Baltimore: The Johns Hopkins University Press, 1973), 19-20. Herbert Butterfield also provides a useful study of teleological history in Herbert Butterfield, The Whig Interpretation of History (New York: WW Norton \& Company, 1981).

${ }^{74}$ Edward Said, Orientalism (Toronto: Random House, 1994), 71.

${ }^{75}$ Daniel, Islam and the West, 209.
} 
Christianity. ${ }^{76}$ Islam would continue to pose a threat to a viable Christian identity so long as it resisted inclusion within an integrative Christian narrative of the world.

\section{Conclusion}

Despite his being better informed about Islam than many of his colleagues, Peter the Venerable did not radically shift how medieval Christians perceived this other. In a sense, the Toledan Collection, which Peter only cited occasionally, served little more than to provide his writings on Islam with a veneer of authenticity, in much the same way that the mysterious Muhammad, the fifth member of Peter's team of translators, served as a speechless testimony to the veracity of Robert of Ketton's translation of the Qur'ān. Peter's legacy was hardly the ecumenical "love of... neighbor" for which Pope Benedict XVI recently praised him—-though he did use his intellectual gifts to ably "guid[e] his monastery and order through tumultuous times.",77 Peter the Venerable's brilliant, if deeply flawed, portrayal of Islam was merely one component of that larger project.

\footnotetext{
${ }^{76}$ Tolan, Sons of Ishmael, 47, 60.

77 Sarah Delaney, "Medieval abbot an example of love for God and neighbor, pope says," Catholic News Service, October 14, 2009, http://www.catholicnews.com/data/stories/cns/0904583.htm.
} 


\section{Bibliography}

Abdul-Raof, Hussein. Qur'an translation: discourse, texture and exegesis. Richmond: Curzon Press, 2001.

Al-Amri, Waleed B. “Qur’ān Translation and Commentary: An Uncharted Relationship?” Islam \& Science 8.2 (2010): 81-110.

Al-Dhahabī, Muḥammad. Siyar A 'lām al-Nubalä' 8 vols. Beirut: Mu'assasat al-Risālah, 1981.

Al-Mișrī, Ahmad b. Naqīb. Reliance of the Traveller: A Classical Manual of Islamic Sacred Law. Translated by Nuh HM Keller. Amana Publications: Beltsville, 1999.

Burman, Thomas E. Reading the Qur'ann in Latin Christendom, 1140-1560. Philadelphia: University of Pennsylvania Press, 2007.

“Tafsīr and Translation: Traditional Arabic Qur'ān Exegesis and the Latin Qur'āns of Robert of Ketton and Mark of Toledo.” Speculum 73.3 (1998): 703-732.

Butterfield, Herbert. The Whig Interpretation of History. New York: WW Norton \& Company, 1981.

Copeland, Rita. Rhetoric, Hermeneutics, and Translation in the Middle Ages: Academic Traditions and Vernacular Texts. Cambridge: Cambridge University Press, 2003.

Daniel, Norman. Islam and the West: The Making of an Image. Oxford: Oneworld Publications, 2000.

Delaney, Sarah. "Medieval abbot an example of love for God and neighbor, pope says." Catholic News Service, October 14, 2009. Accessed December 9, 2011.

http://www.catholicnews.com/data/stories/cns/0904583.htm.

Dolgopolski, Sergey. What is Talmud?: The Art of Disagreement. New York: Fordham University Press, 2009.

Ibn ‘Āshūr, Muhammad al-Fāḍil. Al-Tafsì wa-Rijälubū. Cairo: Al-Azhar, 1970.

Iogna-Prat, Dominique. Order and Exclusion: Cluny and Christendom Face Heresy, Judaism, and Islam (1000-1150). Translated by Graham R Edwards. Ithaca: Cornell University Press, 2002.

Iqbal, Muzaffar. "Reading the Qur'ān in Latin Christendom, 1140-1560 (Review).” Islam \& Science 6.1 (2008): $55-59$.

. “The Qur'ān and its Disbelievers.” Islam \& Science 7.2 (2009): 87-126.

Kritzeck, James. Peter the Venerable and Islam. Princeton: Princeton University Press, 1964.

Mastnak, Tomaž. Crusading Peace: Christendom, the Muslim World, and Western Political Order. Berkeley: University of California Press, 2002.

Nirenberg, David. Communities of Violence: Persecution of Minorities in the Middle Ages. Princeton: Princeton University Press, 1998.

Online Etymology Dictionary. “Saracen.” Accessed December 28, 2011. http://www.etymonline.com/index.php?term=Saracen.

Pickering, Frederick P. "Economies of History. What is Fiction?" In Essays on Medieval German Literature and Iconography, 164-74. Cambridge: Cambridge University Press, 1980.

Reeves, Minou. Muhammad in Europe. New York: New York University Press, 2000.

Rubin, Miri. Gentile Tales: The Narrative Assault on Late Medieval Jews. Philadelphia: University of Pennsylvania Press, 2004.

Said, Edward. Culture and Imperialism. New York: Random House, Inc., 1994.

Orientalism. Toronto: Random House, 1994. 
. "The Problem of Textuality: Two Exemplary Positions.” Critical Inquiry 4.4 (1978): 673-714.

Tolan, John V. "Introduction." In Medieval Christian Perceptions of Islam: A Book of Essays. Edited by John V Tolan. New York: Garland Publishing, 1996.

- Saracens: Islam in the Medieval European Imagination. New York: Columbia University Press, 2002.

- Sons of Ishmael: Muslims through European Eyes in the Middle Ages. Gainesville: University Press of Florida, 2008.

White, Hayden. Metahistory: The Historical Imagination in Nineteenth-Century Europe. Baltimore: The Johns Hopkins University Press, 1973. 